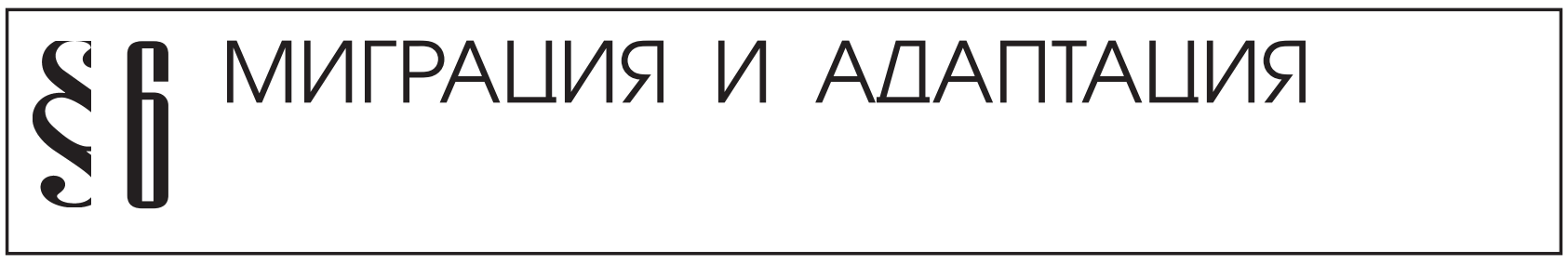

Филиппенко А.А.

\title{
«МЕЧТАТЕЛИ» В США: ИСТОРИЯ ВОЗНИКНОВЕНИЯ ПОЛИТИЧЕСКОГО ДВИЖЕНИЯ МОЛОДЫХ НЕЛЕГАЛЬНЫХ ИММИГРАНТОВ
}

Аннотация: Статья рассказывает о становлении в США волонтёрских организаций молодых нелегальных иммигрантов, борюшихся за принятие нового иммиграционного законодательства. С 2001 г. в США начали возникать объединения студентов, выступающих за то чтобы нелегальным иммигрантам, въехавщим 8 страну детьми было дано право на постоянное пребывание и работу. Первоначально независимые группь молодых нелегальных иммигрантов были объединены крупными лоббистами, но смогли преодолеть их влияние и переросли в самостоятельное политическое движение. Исследование проводилось при помощи анализа воспоминаний и интервью непосредственных участников объединения молодых нелегальных иммигрантов (политиков, лоббистов, волонтёров движения) и систематизации статей ведущих политических изданий. Молодежное движение оказало значительное воздействие на иммиграционную политику США, что не удалось многочисленным крупным лоббистским организациям. Несмотря на противодействие конгресса, президент подписал меморандум, который отвечал основным требованиям молодых нелегальных иммигрантов, предоставив им визы на 2 года с возможностью продления. Такой исход был определён смелостью участников движения, которые смогли выйти из-под опеки крупных организаиий и действовать самостоятельно.

Review: The article tells the story of formation of the volunteer organizations of young illegal migrants fighting for the new immigration legislation in the USA. From 2001 on in the US there appeared student associations, being in favor of providing the permanent stay and working permits for the illegal migrants, who were brought into the USA, when they were children. While being initially independent, the groups of young illegal migrants were brought together by large lobbying groups, but they have managed to overcome influence of these groups, and they formed an independent political movement. The study involved analysis of stories and interviews of participants of the movement of young illegal migrants (politicians, lobbyists, volunteers of the movement) and systematization of the articles of leading political publications. The youth movement had a significant influence upon the migration policy of the USA, while numerous lobbying organizations failed to deal with this task. In spite of opposition of the Congress, the President has signed a memorandum, which met the main requirements of the young illegal migrants, providing them with 2 years visas with the possibility of period extension. Such a result was achieved thanks to the bravery of participants of the movement, who have managed to escape control of the large organizations and act independently.

Ключевые слова: «Мечтатели», нелегальные иммигранты, иммиграционная реформа, конгресс, президент, законопроект, депортация, лобби, амнистия, иммиграционная политика.

Keywords: "Dreamers", illegal migrants, immigration reform, congress, president, legislative draft, deportation, lobby, amnesty, immigration policy.

И ммиграционная реформа в США на протяжении десятилетий остаётся одной из самых острых политических тем. Она касается сотен тысяч жителей страны и миллионов желающих приехать жить, учиться или временно работать в США. Законопроекты об иммиграционной реформе вносятся на рассмотрение Конгресса почти каждый год. С начала XXI в. предложения по реформе направлены на решение следующих задач: обеспечение безопасности границ, совершенствование визовой системы для балансирования рынка труда и привлечения высококвалифицированных специалистов, а также решение вопроса о проживающих на территории США по разным подсчётам от 10 до 12 миллионов нелегальных иммигрантов. Последняя задача вызывает самые острые споры. Не- 
которые законопроекты предлагают «амнистию» (получение легального статуса и в дальнейшем гражданства) для нелегальных иммигрантов. Другие наоборот, предполагают депортацию всех нарушивших иммиграционное законодательство США. Вне зависимости от политической направленности, законопроекты по иммиграционной реформе редко доходят до обсуждения согласительным комитетом обеих палат Конгресса.

Последний подписанный президентом закон об иммиграции был принят в 1990 г. и значительно устарел. С тех пор изменились иммиграционные потоки и иммиграционная политика страны, было принято множество подзаконных актов и поправок, что сделало всю систему громоздкой, неповоротливой и забюрократизированной. Необходимость реформы очевидна, но также понятна и сложность её обсуждения. Каждый раз когда в Конгресс вносится предложение о новом законопроекте, страну охватывает волна выступлений, пикетов и маршей. Уже долгие годы общественное мнение разделено почти поровну: часть американцев выступает за «амнистию», предоставление права на проживание нелегальным иммигрантам, другая ратует за массовые депортации всех, кто нарушил иммиграционное законодательство. Из-за того что конгрессмены боятся потерять кресло и не спешат принимать спорные решения, реформу иммиграционного законодательства откладывается годами.

Конгресс не занимается всеобъемлющей иммиграционной реформой, но принимает акты об укреплении границы и попасть в страну нелегально становится сложнее, одновременно те, кто уже нелегально проживает на территории США не уезжают. Нелегалы продолжают работать и воспитывать детей. Каждый год школу заканчивают около 65 тысяч нелегальных иммигрантов живущих в США более 5 лет, сотни тысяч детей незаконно находящихся в стране не представляют себе другой родины кроме США. Они ходят в школу наравне со своими друзьями гражданами США благодаря решению Верховного суда от 15 июня 1982 г. По делу «Плайер против Доу» Верховный суд постановил, что лишение ребёнка права на образование существенно сказывается на его социальном, интеллектуальном, и психологическом развитии, а также на экономическом благополучии. По мнению судей, штаты не должны отказывать в праве на школьное образование на основании гражданства, если ребёнок постоянно проживает на территории США.

В отношении этой группы нелегальных иммигрантов мнения американцев расходятся не так резко. И согласно опросам граждане США готовы предоставить разрешение на пребывание тем детям, которые были ввезены в страну по решению своих родителей ${ }^{1}$. Но согласно закону этих детей могут депортировать наравне с теми, кто самостоятельно принял решение о незаконном пересечении границы или сознательно просрочил свою визу.

Дети нелегальных иммигрантов могут и не подозревать о своём статусе, пока не закончат школу или пока не столкнуться с возможностью депортации. В начале 2000-х гг. количество выдворений из США достигло 183000 человек, 70000 из них были задержаны в связи с нарушением законодательства США и 113000 были задержаны во время рейдов по поиску нелегальных иммигрантов ${ }^{2}$. Более половины выдворенных из страны нелегалов не подозревались в каком-либо преступлении и не были частью преступных групп. Тем не менее средства на их поиск и задержание были потрачены не малые и тогда законодатели начали задумываться о необходимости расставлять приоритеты и в первую очередь сконцентрировать силы и средства для выдворения тех, кто может представлять угрозу. В ноябре 2000 г. руководитель службы иммиграции и натурализации Д. Мейснер опубликовала меморандум, в котором говорилось о необходимости концентрироваться на депортации тех нелегальных иммигрантов, которые могут представлять потенциальную угрозу для США или их граждан. Также там содержалось указание не заниматься преследованием молодых иммигрантов, у которых нет разрешения на постоянное пребывание, но которые могли бы на него претендовать в других обстоятельствах ${ }^{3}$. Меморандум вызвал шквал критики со стороны антииммиграционных групп, которые выступали за

\footnotetext{
${ }^{1}$ First Focus "Public support for the DREAM act" June, 2010 http://www.firstfocus.net/sites/default/files/dreampollbreakdown_0.pdf

2 The INS escort of criminal aliens report June 2001, US Department of Justice http://www.justice.gov/oig/reports/INS/e0105/ background.htm

${ }^{3}$ Contreras J. "Deferred action: recommendations to improve transparency and consistency in the USCIS process", Department of homeland security 11 July 2011 http://www.dhs.gov/ xlibrary/assets/cisomb-combined-dar.pdf
} 


\section{Политика и общество 7 (115) • 2014}

депортацию всех нелегальных иммигрантов вне зависимости от того, представляют они угрозу для страны или нет. Но одновременно этот меморандум стал сигналом для тех, кто выступает за амнистию нелегальным иммигрантам.

В конце 2000 г. один из известных лоббистов, директор вашингтонского офиса Национального правового иммиграционного центра Д. Бернштейн предложил свой вариант законопроекта по защите детей одному из борцов за права иммигрантов в Конгрессе - Л. Гутьересу. Разработка текста и обсуждение деталей заняло всю зиму, а в апреле 2001 г. Л. Гутьерес внёс на обсуждение Палаты представителей законопроект «о недопущении ограничений обучения детей иммигрантов» (H.R. 1582) в котором предусматривалось:

- $\quad$ предоставление статуса «защиты от депортации» тем, кто был нелегально ввезён на территорию США до 16 лет

- предоставление разрешения на постоянное пребывание в случае если нелегальный иммигрант:

- был ввезён на территорию США до 16 лет,

- проживает в США не менее 5 лет,

- не достиг возраста 25 лет,

- у учится в школе, колледже или институте,

- $\quad$ не имеет административных или уголовных взысканий и может предоставить рекомендательные письма

- $\quad$ предоставление права на получение грантов на обучение в колледже или институте ${ }^{4}$

Как уже говорилось, нелегальные иммигранты могли учиться в школе, но поступать в высшие учебные заведения они могли только за плату наравне со всеми иностранными студентами. Им не предоставлялось право на гранты, которые могли получить граждане США для бесплатного обучения. Законодатели хотели дать нелегальным иммигрантам приехавшим в страну до 16 лет и проживающим с США не менее 5 лет возможность соревноваться за получение грантов. На протяжении мая и июня законопроект обсуждался в нескольких подкомитетах Палаты. 27 июня был передан на обсуждение в подкомитет по реформе образования, где и был «похоронен». Нижняя палата оказалась не готова для

${ }^{4}$ H.R. 1582 Immigrant children's educational advancement and dropout prevention act of 2001, $107^{\text {th }}$ Congress 2001-2002 http://beta.congress.gov/bill/107th-congress/house-bill/1582 такого законопроекта, но на него обратили внимание в Сенате.

Как раз весной 2001 г. демократы Э. Кеннеди и Р. Дурбин активно вели переговоры с республиканскими сенаторами относительно принятия всеобъемлющей иммиграционной реформы. Все соглашались, что реформа необходима, но в связи с растущей популярностью демократов у выходцев из Латинской Америки, республиканцы хотели показать, что благодаря стараниям их партии реформа будет проведена в жизнь. В Сенате считали законопроект Гутьереса удачным и когда он провалился в Палате именно республиканец О. Хэтч представил подобный билль.

Законопроект «Развитие, помощь и образование для несовершеннолетних иммигрантов» (DREAM Act S.1291) был внесён на рассмотрение в августе 2001 г. и предусматривал следующее:

- предоставление статуса «защиты от депортации»:

- тем, кто был нелегально ввезён на территорию США до 16 лет

- $\quad$ не моложе 12 лет и не старше 21 года на момент принятия закона

- непрерывно проживает на территории США по крайней мере 5 лет

- $\quad$ имеет диплом об окончании школы в США или учится в старших классах

- $\quad$ не имеет административных или уголовных взысканий

- $\quad$ предоставление права на получение гранта для обучения в американском ВУЗе, в случае, если на грант не претендует гражданин США

Авторы законопроекта готовились его защищать, но через месяц после представления S. 1291 произошли теракты, потрясшие США и весь мир. Законодатели сконцентрировались на проблеме охраны границ.

Многие законопроекты, касавшиеся иммиграционной политики, в том числе «развитие, помощь и образование для несовершеннолетних иммигрантов», легли на полку как только стало известно, что самолётами, врезавшимися в пентагон и башни всемирного торгового центра управляли иностранцы. В обществе значительно ухудшилось отношение к иммигрантам, нелегальных иммигрантов заклейми-

${ }^{5}$ S.1291 DREAM Act, $107^{\text {th }}$ Congress $2001-2002$ http://beta. congress.gov/bill/107th-congress/senate-bill/1291? 
ли как «потенциальную угрозу», а иммиграционная реформа была выделена из социальных проблем и перенесена к вопросам обеспечения безопасности ${ }^{6}$. Постепенно начали возрождаться антииммиграционные сообщества, которые активно действовали в 1980-1990 гг.

Положение иммигрантов ухудшало и то, что некоторые официальные лица напрямую связывали нелегалов и террористов. Госсекретарь К. Райс высказала опасения, что террористы могут использовать плохо укреплённую границу США и Мексики в качестве лазейки для проникновения в страну вместе с нелегальными иммигрантами ${ }^{7}$. Из-за подобных опасений было принято несколько законов по укреплению границы, увеличению количества патрулей и внедрению новейших технологий слежения. Усилия дали свои результаты: за 2001 г. были высланы около 200000 нелегальных иммигрантов, за 2005 г. - 300 000, за 2012 - 400 000. Но среди этих людей были не только задержанные на границе, но и те самые дети нелегальных иммигрантов.

Конгрессмены предлагали разные версии законопроекта «Развитие, помощь и образование для несовершеннолетних иммигрантов» в 2003, 2004, 2005 гг. Его прикрепляли в качестве поправки к законопроектам Кеннеди-Маккейна 2006 и 2007 г. Его включали в текст законопроекта о всеобъемлющей иммиграционной реформе в 2009 и 2010 гг. Но законопроект так и не был принят. Противники любого вида легализации первоначально давили на то, что нелегальные иммигранты и их дети представляют потенциальную террористическую угрозу. Со временем, вместе с укреплением границы акцент антииммиграционных групп сместился и к середине 2000-х гг. они стали говорить, что выступают против легализации детей проживающих в США без документов из-за опасности «цепной миграции». Если детям нелегальных иммигрантов дать возможность получить разрешение на постоянное пребывание, то в дальнейшем они смогут получить гражданство, а значит пригласить сво-

\footnotetext{
${ }^{6}$ Camarota S. "Immigration and Terrorism", Center for Immigration studies, 12 October, $2001 \mathrm{http}: / /$ cis.org/Immigration Policy\%2526Terrorism

${ }^{7}$ Weisman S., Thompron G. Rice and Mexican official hint at thaw in relations, The New York Times, 11 March 2005 http:// www.nytimes.com/2005/03/11/international/americas/11diplo. html?_r=0
}

их родителей и родственников, которые тоже смогут получить гражданство. Антииммиграционное лобби пугало американцев наплывом иммигрантов и в связи с неопределённостью общественного мнения, законодатели не спешили принимать новый закон. Политики не решались действовать и в обществе постепенно возникало волонтёрское проиммиграционное движение.

С 2001 г., в разных учебных заведениях по всей Калифорнии начали образовываться небольшие группы, популяризировавшие идею принятия законопроекта «Развитие, помощь и образование для несовершеннолетних иммигрантов» (DREAM Act) в среде своих сверстников. Каждая новая попытка обсуждения иммиграционного законодательства в Конгрессе подталкивала молодых людей на присоединение к движению. По первым буквам английского названия (Development, Relief, and Education for Alien Minors) сторонников законопроекта стали называть «мечтатели» - DREAMers. Движение зародилось для того, чтобы добиться легализации людей въехавших в США детьми и в нём участвовали в основном студенты, которые сами были нелегалами, но родители которых смогли найти деньги для их обучения в ВУЗах без грантов. Большинство из них прожили в США почти с рождения и чувствовали себя американцами, поэтому также как и другие американцы были готовы бороться за свои права.

В 2003 г. в Калифорнии было организовано Калифорнийское сообщество «мечтателей», в которое входило несколько десятков студентов со всего штата. После очередного неудачного обсуждения законопроекта «развитие, помощь и образование для несовершеннолетних иммигрантов» молодые участники движения из Калифорнии решили приехать в Вашингтон, где устроили пикет перед Капитолием. Они выложили эту информацию в интернет и их приехали поддержать сотни студентов из разных штатов. Тогда на них обратила внимание пресса и небольшие группы «мечтателей» стали возникать по всей стране.

Пока в США возникали разрозненные группы «мечтателей», крупные организации, продвигающие идею иммиграционной реформы решили объединить свои усилия для более сплочённой работы. Такие крупные лоббисты как Национальный правовой иммиграционный центр, Национальный совет Ла Раса, Национальный иммиграционный форум и Мексикано-американский фонд юридической 


\section{Политика и общество 7 (115) • 2014}

защиты и образования объединились в Движение справедливой иммиграционной реформы. Каждый из участников выделил сотрудника, задачей которого стало координировать работу организаций по всей стране для продвижения идеи иммиграционной реформы в прессе и среди законодателей. С координаторами движения стали выходить на связь представители разных групп «мечтателей» из разных штатов и предлагать свои услуги в качестве волонтёров. И руководители Движения справедливой иммиграционной реформы приняли решение попытаться объединить «мечтателей» между собой. Так возникла идея создания коалиции «Мы мечтаем вместе» (“United we dream")

На протяжении 2005-2006 гг. шло обсуждение того, как можно объединить группы детей нелегальных иммигрантов, которые самостоятельно пытаются рекламировать законопроект «развитие, помощь и образование для несовершеннолетних иммигрантов», но лишены средств и юридического основания их собирать, а также не имеют общей идеологии и программы, зачастую говорят на разных языках и живут в разных концах страны. В 2007 г. Национальный правовой иммиграционный центр решил взять на себя ответственность по работе с детьми нелегальными иммигрантами и выделил средства для объединения разрозненных групп «мечтателей» в коалицию Мы мечтаем вместе. Первоначальный план заключался в том, чтобы воспользоваться уже налаженной системой связи «мечтателей» с местным населением для продвижения всеобъемлющей иммиграционной реформы. Совет директоров Мы мечтаем вместе был собран из руководителей крупнейших групп «мечтателей». В связи с тем, что подавляющим большинством в коалиции Мы мечтаем вместе были нелегальные иммигранты, юридические вопросы взял на себя Национальный правовой иммиграционный центр, а офис Мы мечтаем вместе расположился в их здании. Первой задачей коалиции стала выработка единого подхода к формированию общественного мнения и чёткое формулирование своих требований.

Все, кто причислял себя к «мечтателям» сталкивались с одними и теми же проблемами, их главным желанием было получить легальный статус для того чтобы можно было учиться и работать в той стране,

${ }^{8}$ Our History, United We Dream http://unitedwedream.org/ about/history/ где они прожили большую часть своей жизни. Поэтому целью коалиции стало добиться принятия законопроекта «развитие, помощь и образование для несовершеннолетних иммигрантов». Для преодоления негативного отношения к законопроекту, необходимо было показать американцам, кто получит право на гражданство, если он будет подписан президентом. Коалиция «мечтателей» решила представить своих членов следующим образом:

1. Де факто американцы. Носители американских ценностей (само слово «мечта» в первую очередь ассоциируется с «американской мечтой»), которые прекрасно говорят на английском, любят ту же музыку и те же книги, что их одноклассники граждане США. Основной посыл ничем не отличаются от среднестатистических американцев своего возраста

2. Лучшие из лучших. Отличники и хорошисты, нравственные, успешные, не имеющие административных или уголовных взысканий. Основной посыл - внесут вклад в страну

3. Ни в чём не виноваты. Они не делали сознательный выбор в пользу нарушения иммиграционного законодательства, решение за них приняли родители. Основной посыл - не должны расплачиваться за ошибки своих родителей «Мечтатели» находили самые разные способы для привлечения внимания - от фестивалей национальной кухни (где неизменно звучала американская популярная музыка) до выступлений и проведения дебатов в университетах. Руководители коалиции раздавали интервью, на сайте «мечтателей» каждую неделю выкладывали пресс-релизы, где рассказывалось о мероприятиях и выступлениях членов Мы мечтаем вместе. Коалиции удалось успешно донести своё видение «мечтателей» до общества и политиков. Лидер большинства в Сенате Г. Рид в интервью Нью Йорк Таймс заметил: «те, кто получат легальный статус благодаря законопроекту DREAM, сделают нашу страну более конкурентоспособной, они будут платить налоги, создавать новые кампании, а значит новые рабочие места и способствовать ассимиляции своих общин» ${ }^{9}$. Министр внутренней безопасности Д. Наполитано также высказалась за принятие законопроекта: «хорошие

${ }^{9}$ Herszenhorn D. "Reid trying again on immigration bill", The New York Times 17 November 2010 http://thecaucus.blogs.nytimes.com/2010/11/17/reid-trying-again-on-immigration-bill/ 
студенты, которые проживают в США нелегально не виноваты в том, что родители привезли их сюда, эти дети не преступники» ${ }^{10}$.

Идеи были донесены верно, но тут же возникла неожиданная проблема. «Мечтателей» представили «хорошими иммигрантами», которые уже ассимилировались, прекрасно учатся и обладают высокими моральными качествами, а главное не виноваты в том, что они проживают в США без разрешения властей. Но тогда получается, что другие иммигранты, те кто не обладают всеми перечисленными качествами (пока не ассимилировались или не учатся на отлично или сознательно решили приехать в страну нелегально) - «плохие иммигранты». В таком случае даже родители «мечтателей» не попадают под определение «хороших иммигрантов» (хотя могли давно ассимилироваться и быть высокими профессионалами своего дела) так как сознательно нарушили иммиграционное законодательство. Бывший директор калифорнийского сообщества «мечтателей» отметил: «такой подход закрепляет понятие о «хорошем» и «плохом» иммигранте. Хороший это тот, что выглядит и говорит как американец. А плохой - тот, кто выглядит иначе и не учит английский» ${ }^{11}$.

С 2009 г. «мечтатели» выбрали другую тактику: вместо того, чтобы стараться создать единый образ «хорошего» иммигранта, они стали предавать огласке самые яркие и интересные истории всех членов коалиции. Такой подход оказался крайне успешным, американцев трогали личные истории «мечтателей». В Интернет выкладывались видео, где совершенно разные подростки на идеальном английском рассказывали историю своей семьи и иммиграции, вспоминали первые впечатления об Америке, делились мечтами и стремлениями. В социальных сетях появилось множество групп поддержки «мечтателей», на сайте сенатоpa Р. Дурбина появилась страничка, где можно было прочитать истории «мечтателей» и поделиться своей, теперь главной целью стало продвижение идеи: мы разные, но все мы американцы.

10 Preston J. Napolitano backs immigration bill The New York Times 2 December $2010 \mathrm{http}$ ://thecaucus.blogs.nytimes. com/2010/12/02/napolitano-backs-immigration-bill/

${ }^{11}$ Nicholls $W$. The DREAMers. How the Undocumented youth movement transformed the Immigrant Rights debate, Stanford: Stanford University Press, p.58
Многие политики упоминали в своих выступлениях «мечтателей», а сами участники движения возлагали большие надежды на нового президента. В 2009 г. после инаугурации Б. Обамы сторонники иммиграционной реформы были уверены в скором принятии закона, куда обязательно будет включён и законопроект «развитие, помощь и образование для несовершеннолетних иммигрантов». Но спад на финансовом рынке, банкротство предприятий и необходимость выводить экономику из рецессии занял всё внимание законодателей, поэтому «мечтатели» решили бросить все силы на продвижение законопроекта в обществе. К 2009 г. движение насчитывало уже несколько десятков тысяч активных членов и волонтёров, потенциально «мечтателей» было около миллиона. За несколько лет работы Мы мечтаем вместе удалось собрать достаточную базу поддержки и благодаря пожертвованиям стать финансово независимыми от Национального правового иммиграционного центра.

Зимой 2009 г. конгрессмен Л. Гутьерес заявил о начале тура «Воссоединение семьи», цель которого - исключить возможность депортации лиц, чьи дети, жены или мужья являются гражданами США. Благодаря стараниям Национального совета Ла Раса и Национального правового иммиграционного центра Гутьерес включил «мечтателей» в число тех, кто выступал на сцене. Тур проходил по всей стране, только за зиму 2009 г. было охвачено 25 штатов. Во всех городах Гутьерес призывал американцев звонить своим представителям в Вашингтон и высказывать требование о принятии нового иммиграционного законодательства. Каждый раз конгрессмен говорил о «мечтателях», вызывал на сцену участников движения, которые делились своими историями. «Хорошие иммигранты» нравились прессе, которая с удовольствием печатала трогательные истории мечтающих жить и работать в США. От города к городу популярность тура возрастала, и на одном из выступлений Гутьерес заявил, что два конгрессмена Р. Дурбин и Г. Берман, объединились для разработки нового законопроекта на основании «развития, помощи и образования для несовершеннолетних иммигрантов». Новая версия состояла из следующих положений:

1. Нелегальные иммигранты, которые

- прибыли в США в возрасте до 16 лет

- постоянно проживают на территории страны более 5 лет 


\section{Политика и общество 7 (115) • 2014}

- успешно сдали экзамены в университет или уже имеют диплом о высшем образовании или готовы служить в армии США более двух лет

- $\quad$ не привлекались к административной или уголовной ответственности

- $\quad$ имеют хорошие рекомендации

- могут подать прошение о получении разрешения на постоянное пребывание

2. Тем из них, кто поступил в высшее учебное заведение предоставляется право на получение некоторых типов грантов на обучение

Отличие этого законопроекта от предыдущих заключалось в возможности получить разрешение на постоянное пребывание в случае заключения контракта на службу в армии. Также демократам удалось привлечь на свою сторону республиканцев Ричарда Лугара и Линкольна Диаса-Баларта благодаря тому, что были добавлены следующие ограничения, которых не было в других подобных законопроектах:

- $\quad$ законопроект покрывает лиц младше 35 лет

- гранты на обучение не включают самый распространённый тип - федеральный студенческий грант Пелла ${ }^{12}$

«Мечтатели» приложили максимум усилий для позитивного освещения законопроекта в прессе. Представители Мы мечтаем вместе проводили по всей стране тренинги и мастер-классы для того чтобы местные «мечтатели» могли чётко выражать свои мысли и доносить свою позицию в разных аудиториях. Коалиция выпускала множество рекламной продукции, в Вашингтоне прошел марш «мечтателей», в разных городах устраивались пикеты и шествия. Коалиция Мы мечтаем вместе координировала все акции и показала себя реальной силой, сумев собрать сотни молодёжных групп, продвигающих принятие нового закона. Несмотря на существование финансовых средств, их явно не хватало для таких обширных акций и «мечтатели» снова обратились к Национальному правовому иммиграционному центру. Деньги оказались потрачены не зря - «мечтателям» удалось создать обширную базу, «армию мечтателей» и вывести законопроект на первые полосы местных газет по всей стране. Тем не менее в день представления 26 марта 2010 г. законопроект был отправлен на доработку в под-

${ }^{12}$ S. 729 DREAM Act of $2009111^{\text {th }}$ Congress 2009-2010 http:// beta.congress.gov/bill/111th-congress/senate-bill/729 комитеты палат, где и был «похоронен». С точки зрения продвижения законодательства это стало неудачей, но именно тогда «мечтатели» поняли, что могут стать самостоятельным, весомым политическим движением ${ }^{13}$. После провала законопроекта на встречах про-иммиграционных кругов некоторые «мечтатели» выступали за то, чтобы ещё раз попробовать представить «развитие, помощь и образование для несовершеннолетних иммигрантов» как отдельный законопроект, но большинство лоббистов высказались против, тем более, что президент заявил, что поддержит именно всеобъемлющий законопроект ${ }^{14}$. Крупные лоббистские организации решили заняться продвижением большой всеобъемлющей реформы, а «мечтателей» сделать «лицом» этой компании. «Хорошие иммигранты» должны были доказать гражданам США, что в реформе нет ничего страшного.

Движение справедливой иммиграционной реформы, в которое входил главный спонсор «мечтателей» Национальный правовой иммиграционный центр, ежегодно тратило миллионы долларов своих членов на проведение массовых акций в поддержку законопроектов всеобъемлющей реформы. В 2010 г. деньги движению были выделены на освещение и поддержку принятия «всеобъемлющей иммиграционной реформы для безопасности и процветания Америки» (H.R. 4321). Законопроект не был принят, а акции не получили освещения в федеральной прессе, деньги оказались потрачены впустую. Про-иммиграционные организации остались крайне не довольны таким исходом и некоторые заявили о выходе из движения и концентрации на борьбе за локальные законопроекты.

Коалиция Мы мечтаем вместе решила согласиться с необходимостью бороться за принятие всеобъемлющей реформы, так как после финансирования акций в поддержку законопроекта Дурбина-Бермана снова оказалась в положении зависимом от Движения справедливой иммиграционной реформы. Но от коалиции откололась радикальная часть «мечтателей», их было всего около 100 чело-

\footnotetext{
${ }^{13}$ Nicholls $W$. The DREAMers. How the Undocumented youth movement transformed the Immigrant Rights debate, Stanford: Stanford University Press, p.74

${ }^{14}$ Press Priefing by press-secretary Robert Gibbs, The White House http://www.whitehouse.gov/the_press_office/Briefingby-White-House-Press-Secretary-Robert-Gibbs-6-25-09
} 
век, но они громко заявили о себе. Радикалы опубликовали манифест в котором говорилось: «Мы активисты движения молодых нелегальных иммигрантов отказываемся продолжать молчать... Мы не хотим больше ждать. Мы разработали свою стратегию и тактику и отказываемся от пассивности неправительственных организаций. Когда надежда угасала мы укрепили сеть единомышленников готовых действовать. И мы объявляем себя иммигрантами без документов и без страха!» ${ }^{15}$

Радикальная часть «мечтателей» решила провести свою собственную акцию и показать, что бороться за законопроект DREAM можно и без значительных трат. Четыре студента из Флориды организовали четырехмесячный пеший проход из Майами в Вашингтон, назвав его «путь мечты». Поход привлёк значительное внимание прессы, его освещали в крупнейших газетах и в популярных телевизионных передачах, через социальные сети к флоридским «мечтателям» присоединялись активисты из разных частей страны. 1 мая 2010 г. они приняли участие в массовой сидячей забастовке у ступеней Капитолия, которая закончилась арестом нескольких десятков человек и в том числе конгрессменов. Акция имела большой резонанс и через социальные сети собрала воедино группы тех, кто хотел отделиться от Мы мечтаем вместе. Активисты из Лос Анджелеса, Чикаго, Мичигана, Нью Йорка и Майами объединились в движение «Мечта на пороге» (“The Dream is Coming”). Основным спонсором движения стало Калифорнийское сообщество «мечтателей». Также финансовую помощь оказывали Мексикано-американский фонд юридической защиты и образования, Национальная сеть подённых рабочих и Трудовой центр университета Лос Анджелеса.

В мае прошли несколько акций гражданского неповиновения Мечты на пороге: 17 мая четыре студента - нелегальных иммигранта и один гражданин США оккупировали офис сенатора Маккейна, отказывались уходить, требуя принятия закона «развитие, помощь и образование для несовершеннолетних иммигрантов». Акция вызвала колоссальный резонанс в прессе, через день колонка

${ }^{15}$ Domingues $N$. "DREAM activists: rejecting the passivity of the nonprofit, industrial complex" Truthout, 21 September 2010 http://www.truth-out.org/archive/item/91877:dream-activistsrejecting-the-passivity-of-the-nonprofit-industrial-complex редактора Нью Йорк Таймс вышла целиком посвященная этой акции, в номере было несколько статей на эту тему, журналисты посчитали, что студенты достойны такого внимания: «кто еще так смело рисковал всем в эти долгие годы борьбы за иммиграционную реформу?» ${ }^{16}$ На следующий день более ста студентов нелегалов устроили сидячую забастовку у федерального здания в Лос Анджелесе, девять из них были арестованы. В конце мая радикальные «мечтатели» заявили о голодовке до принятия закона. Сотни сторонников Мечты на пороге организовали автопробег по США. В июле они попытались устроить сидячую забастовку в офисах конгрессменов, но 21 человек был арестован и акция прервалась. Коалиция Мы мечтаем вместе была в замешательстве - с одной стороны они хотели поддержать своих друзей, а с другой не хотели терять поддержку крупных лоббистов.

В июльской речи об иммиграционной реформе Обама подчеркнул своё намерение укреплять границы и заметил, что за год вдвое увеличилось количество пограничников в три раза увеличилось количество сотрудников разведслужбы на границе с Мексикой. Только с лета 2010 г. таможня смогла без задержек просматривать на рентгене все без исключения посылки, переправляемые на территорию США. Пограничная служба стала изымать больше оружия, наркотиков и незаконно ввозимых товаров чем когда-либо, количество преступлений на приграничных территориях значительно снизилось ${ }^{17}$. Подчёркивая успехи в укреплении безопасности границы Белый дом явно готовил почву для продвижения законопроекта по иммиграционной реформе. Тогда же пришло известие о том, что глава крупнейшего профсоюза США Американская федерация труда - конгресс производственных профсоюзов (AFL-CIO) P. Трумка поддерживает законопроект «развитие, помощь и образование для несовершеннолетних иммигрантов». Это было большой победой радикальных «мечтателей», так как именно они через Трудовой центр университета Лос Анджелеса

\footnotetext{
${ }^{16}$ Courage in Arizona, editorial, The New York Times, 19 May 2009 http://www.nytimes.com/2010/05/20/opinion/20thu2. html?_r=0

${ }^{17}$ Remarks by the President on comprehensive immigration reform 1 July, 2010, The White House http://www.whitehouse. gov/the-press-office/remarks-president-comprehensive-immigration-reform
} 


\section{Политика и общество 7 (115) • 2014}

вели переговоры с AFL-CIO. Такой сильный союзник был важен для того, чтобы провести законопроект, но внезапно последовал серьёзный удар.

После выступления президента республиканский сенатор Ч. Грассли опубликовал служебную записку Министерства внутренней безопасности от апреля 2010 г. В ней содержалось указание прекратить задержания потенциальных нелегальных иммигрантов, которые могут получить легализацию согласно закону «развитие, помощь и образование для несовершеннолетних иммигрантов». Обаму и Наполитано тут же обвинили в том, что они хотят провести амнистию без согласования с Конгрессом. Это отчасти подтверждалось опубликованной запиской, в которой предлагалось обсудить, как можно «отложить задержания, не рискуя получить обвинение в узурпации полномочий Конгресса» ${ }^{18}$. Рейтинг доверия к президенту пошел вниз, правые республиканцы заявляли, что Обама намерен наводнить страну иммигрантами, которые отнимают работу у американцев.

Из-за давления антииммиграционного лобби президент и министр внутренней безопасности приняли решение увеличить количество патрулей на границе и ускорить процесс расследования преступлений, связанных с нарушением иммиграционного законодательства. Количество дел, рассматриваемых каждым судьёй по иммиграционным делам увеличилось примерно до 1200 дел в год, что в три раза превышает нагрузку рядового федерального судьи. Каждый день из США депортировали более 1000 человек. При этом исследования иммиграционных потоков показало, что в 2009-2010 гг. въезд нелегальных иммигрантов снизился на две трети в сравнении с 2000-2005 гг. ${ }^{19}$

Высокое число выдворений и ускоренный процесс депортации вызывали острую критику со стороны про-иммиграционных групп и либеральной прессы. Движение Мечта на пороге снова решилось на активные действия. Двадцать

18 "Arizona, Obama, Congress", Migration news, October 2010, Vol.17 \#4 http://migration.ucdavis.edu/mn/more. php?id=3629_0_2_0

19 Passel J., Cohn D. "U.S. unauthorized immigration flow are down sharply since mid-decade" 1 September 2010 PewResearch Hispanic trends project http://www.pewhispanic. org/2010/09/01/us-unauthorized-immigration-flows-are-downsharply-since-mid-decade/ активистов провели сидячую забастовку у Белого дома под руководством Гутьереса. Многие из участников акции, в том числе конгрессмен, были арестованы. Это снова привлекло внимание прессы и общественности к законопроекту DREAM. В связи с тем, что сторонники радикальных «мечтателей» успели обзавестись серьёзной базой поддержки в виде AFL-CIO, Движение справедливой иммиграционной реформы выступило за то, чтобы продвигать законопроект «развитие, помощь и образование для несовершеннолетних иммигрантов» вне всеобъемлющей иммиграционной реформы. Это было безусловной победой радикальных «мечтателей», которые смогли отстоять свою позицию и заставить коалицию крупнейших иммиграционных лоббистов поменять свою точку зрения.

Ноябрьские выборы усилили позиции республиканцев в Сенате и Палате, поэтому сторонники иммиграционной реформы решили попробовать принять законопроект «развитие, помощь и образование для несовершеннолетних иммигрантов» в период до вступления в должность новых конгрессменов. Законопроект было решено совместить с H.R. 5281, который касался депортации нелегальных иммигрантов. В конце ноября сторонники и авторы законопроекта встретились с президентом в Белом доме, он обещал свою поддержку и действительно провёл несколько встреч и бесед с конгрессменами, которых считали сомневающимися. В новом законопроекте максимальный возраст лиц, которые могли подавать прошение о легализации был снижен до 30 лет, остальное осталось прежним.

Благодаря смене позиции Движения справедливой иммиграционной реформы, радикальные «мечтатели» смогли собрать значительное финансирование для проведения акций поддержки законопроекта. Мы мечтаем вместе и Мечта на пороге совместно проводили встречи с гражданами США, выпускали пресс-релизы, распространяли листовки и газеты с подробным описанием законопроекта и его плюсов, снабжали сторонников товарами с символикой «мечтателей», проводили онлайн встречи и лекции. Была проведена колоссальная работа по всей стране и в этот раз действительно приковала к законопроекту внимание прессы. Белый дом всячески поддерживал законопроект, во всех выступлениях, касающихся иммиграционной реформы, Оба- 
ма упоминал «мечтателей». Члены администрации проводили встречи, давали интервью и разъясняли положительные стороны законопроекта ${ }^{20}$.

8 декабря 2010 г. в Капитолии собрались тысячи «мечтателей» и их сторонников, многие были одеты в майки с новыми лозунгами движения «Без документов и без страха», а также «Я существую». Голосование прошло успешно, проиммиграционные круги наконец-то праздновали победу - Палата одобрила H.R. 5281, но радость оказалась не долгой. 18 декабря Сенат проголосовал против законопроекта, «мечтателям» не хватило пять голосов. После голосования президент признался, что провал законопроекта стал «возможно самым сильным разочарованием последних недель» ${ }^{21}$.

Неудача консолидировала «мечтателей», так как умеренные сторонники движения перешли на более радикальные позиции. К. Саведра, директор Мы мечтаем вместе заявил: «Мы вышли из спячки. Теперь мы будем действовать активно и расскажем всей стране о том, кто нас поддерживает, а кто выступает против нас» ${ }^{22}$. В конце декабря Мы мечтаем вместе организовала встречу представители разных подразделений «мечтателей» в Вашингтоне. Повестка встречи была в целом позитивной, ведь только «мечтатели» привлекли к своему законопроекту внимание всей страны, а другие инициативы проиммиграционных кругов не были популярны. Но на встрече обсуждался и раскол, который был успешно преодолён, тем не менее участники встречи сошлись на том, что движение требует обновления.

«Мечтатели» решили, что пришло время децентрализации. Активисты стали создавать кружки и организации «мечтателей» по всей стране, их объединяло только одно - стремление предоставить молодым нелегальным иммигрантам возможность учиться и служить в армии США. Крупные органи-

${ }^{20}$ Miranda L. "Get the facts on the DREAM act" The White House 1 December 2010 http://www.whitehouse.gov/blog/2010/12/01/ get-facts-dream-act

${ }^{21}$ Valencia $S$. "President Obama on Obstruction of the DREAM act: "maybe my biggest disappointment" of last weeks" The White House, 23 December 2010 http://www.whitehouse.gov/ blog/2010/12/23/president-obama-obstruction-dream-act-maybe-my-biggest-disappointment-last-weeks

22 Preston J. "Immigration vote leaves Obama policy in disarray" The New York Times, 18 December 2010 http://www.nytimes. com/2010/12/19/us/politics/19dream.html?_r=0 зации «мечтателей» сознательно пошли на рассредоточение движения, посчитав, что нет необходимости консолидировать и контролировать работу групп в разных штатах, тем более что для этого требовались значительные финансовые ресурсы. А финансирование вело к зависимости от крупных лоббистов.

По всей стране возникли локальные «Команды мечты» ("Dream teams"), которые не были подчинены общему руководству, но поддерживали связь. В такой ситуации не приходилось и говорить о контроле со стороны каких-либо организаций, которые уже сами были заинтересованы в контактах с популярным, ярким и полным жизни движением. С 2011 г. никто больше не был представителем «мечтателей», они сами стали силой, которая заставила считаться с её мнением. На следующей встрече Движения справедливой иммиграционной реформы «мечтатели» присутствовали как полноправные члены.

Летом 2011 г. «команды мечты» объединили усилия для того, чтобы привлечь внимание к депортациям «мечтателей». Каждая группа делала это по-своему, проводя мероприятия, печатая газеты или распространяя информацию о выдворениях молодых нелегальных иммигрантов из США в страны, где они последний раз были в детстве. Об этой проблеме заговорили в прессе, одним из вариантов решения было издание меморандума, прямо запрещающего депортацию лиц, которые могут получить легализацию в случае принятия законопроекта DREAM. Президент счёл это настолько важной темой, что решил посвятить проблемам «мечтателей» своё выступление перед Национальным советом Ла Раса. В речи Обама в общих чертах проговорил свою позицию относительно иммиграционной реформы, когда президент перешел к острому вопросу депортаций, он сказал: «некоторые хотят, чтобы я обошел Конгресс и изменил существующие законы...» прежде чем он смог продолжить свою речь в зале стали слышны молодые голоса: «Да, вы можете!» Обама продолжил: «Но демократия не так работает», он на секунду остановился и зал с несколькими тысячами человек начал скандировать: «Да, вы можете!» ${ }^{23}$ Скандировали это «мечтатели», которые в большом количестве присутствовали на выступлении.

23 DREAM Act update July 27, 2011 Latino Politics Blog http://atinopoliticsblog.com/2011/07/27/dream-act-update-july-27-2011/ 


\section{Политика и общество 7 (115) • 2014}

«Мечтатели» обновляли движение, привлекали на свою сторону тысячи человек и действительно развивались очень успешно. Умеренные республиканцы также начали высказываться за легализацию «мечтателей».

Весной 2012 г. республиканский сенатор М. Рубио подготовил предложения на основании законопроекта «развитие, помощь и образование для несовершеннолетних иммигрантов». По версии Рубио законопроект даёт право на постоянное пребывание молодым людям до 30 лет, которым на момент въезда в страну было менее 16 лет и которые проучились два года в ВУЗе или заключили контракт на службу в армии США. Но основным отличием от предыдущих законопроектов стало то, что Рубио предлагал запретить легализовавшимся иммигрантам в дальнейшем претендовать на гражданство ${ }^{24}$. Молодой республиканский сенатор кубинского происхождения был популярен среди умеренных республиканцев, но этого было явно не достаточно для принятия законопроекта. Белый дом провёл несколько встреч с конгрессменами, которые подтвердили что голосов не хватает. Об этом же свидетельствовали пресс-релизы крупнейших про-иммиграционных организаций. «Мечтатели» в этот раз встали на сторону лоббистов и не проводили значительных акций.

Администрация Белого дома решила действовать до того как Рубио предложит законопроект DREAM на голосование. 15 июня 2012 г. выступая перед журналистами в розарии Белого дома Обама заявил о том, что подписал меморандум с указанием прекратить задержания иммигрантов, которые могут получить легализацию согласно закону «развитие, помощь и образование для несовершеннолетних иммигрантов». Согласно меморандуму под названием Отложенная депортация для въехавших детьми (Deferred Action for Childhood Arrivals - DACA) нелегальным иммигрантам, которые соответствуют строгим критериям (въехали в США до 16 лет, постоянно проживают на территории страны с 15 июня 2007 г., возраст не более 30 лет, не имеют административных и уголовных взысканий, учатся в школе/

${ }^{24}$ Wiseman J. Rubio, in appeal to G.O.P.'s conscience urges compromise on DREAM act, The New York Times, 19 April 2012 http://www.nytimes.com/2012/04/20/us/politics/marcorubio-urges-republicans-to-pass-dream-act.html университете, закончили школу/университет или являются ветеранами армии США) будут предоставлены рабочие визы на два года, с возможностью их последующего продления ${ }^{25}$. В связи с тем, что DACA не закон, а меморандум, лица, которые получат по нему рабочие визы не будут иметь право претендовать на получение гражданства в будущем. Но даже без возможности получить гражданство, меморандум облегчил жизнь более чем миллиону «мечтателей». Решение президента стало не абсолютной победой, но значительно приближало «мечтателей» к ней. Многие говорили о том, что на президента произвела впечатление акция во время его выступления перед Национальным советом Ла Раса. Возможно это так, но главным для «мечтателей» стало то, что их услышали в Белом доме.

Меморандум Обамы ожидаемо вызвал резкую критику республиканцев, однако согласно опросам граждане США поддержали действия президента. По сообщению кампании Блубмерг, среди зарегистрированных избирателей 56\% республиканцев 86\% демократов и 65\% независимых избирателей поддерживают это решение президента ${ }^{26}$. Даже республиканский противник Обамы на президентских выборах М. Ромни (чей советник по иммиграционным вопросам К. Кобах был категорически против DACA) заявил в октябре 2012 г., что если он выиграет выборы, то не отменит меморандум по крайней мере до 2014 г. Ромни не удалось победить на выборах в том числе и благодаря латиноамериканским голосам. 71\% испаноязычного населения США отдали предпочтение Б. Обаме.

Подписание меморандума DACA - победа движения «мечтателей», они стали единственной группой иммигрантов которым удалось самостоятельно отстоять своё право на пребывание в США. С момента принятия последнего Закона об иммиграции 1990 г. в Вашингтоне и по всей стране проходили многомиллионные марши, пикеты и выступления, организованные крупными про-иммиграционными

\footnotetext{
${ }^{25}$ Memorandum from Janet Napolitano, Department of Homeland Security, 15 June 2012 http://www.dhs.gov/xlibrary/assets/ s1-exercising-prosecutorial-discretion-individuals-who-cameto-us-as-children.pdf

${ }^{26}$ Lerer $L$. "Obama immigration policy favored 2-to-1 by likely voters" Bloomberg Business week, 19 June 2012 http://www. businessweek.com/news/2012-06-19/obama-immigration-policy-favored-2-to-1-by-likely-voters
} 
группами. Сотни лоббистов писали книги и давали интервью относительно потенциальных плюсов принятия иммиграционной реформы. Различные каналы снимали документальные фильмы об иммиграционном законодательстве, объясняя необходимость его совершенствования. Политики произносили пламенные речи, актёры, музыканты, художники и писатели участвовали в мероприятиях для продвижения идеи предоставления легального статуса миллионам иммигрантов живущих в США без документов. И ничто из этого не возымело достаточного действия на законодателей и общественное мнение. Только группе молодых нелегальных иммигрантов, которые смогли пройти путь от зависимой группы под руководством крупных лоббистов до независимого децентрализованного движения без единого руководства, удалось заставить президента принять спорное решение накануне выборов.

«Мечтатели» показали удивительный пример самоорганизации и приблизились к своей цели. Закон «развитие, помощь и образование для несовершеннолетних иммигрантов» пока не принят, но молодые люди, прожившие почти всю свою жизнь в США под страхом депортации теперь смогут жить и работать в США без опасений.

К январю 2014 г. на визы по DACA подали около 610 тысяч молодых людей и большинство из них были одобрены (15 тысяч отказов $)^{27}$. «Мечтатели» не прекратили свою работу, теперь они нацелены на то, чтобы добиться принятие закона, который не только предоставит временное право жить и работать в США, но и откроет для них путь к гражданству. Новый лозунг «мечтателей»: «Все мы люди» отражает мысль, которую пытаются донести до граждан США про-иммиграционные движения. У политического движения молодых нелегальных иммигрантов может получится то, что не удавалось лоббистам, политикам, профсоюзам и бизнесу. Возможно «мечтатели» смогут склонить общественное мнение и Конгресс к принятию всеобъемлющей иммиграционной реформы, которая так необходима США.

\footnotetext{
${ }^{27}$ DACA quarterly report US citizenship and Immigration Services, 6 February 2014, http://www.uscis.gov/sites/default/files/ USCIS/Resources/Reports\%20and\%20Studies/Immigration $\% 20$ Forms\%20Data/All\%20Form\%20Types/DACA/DACA-06-0214.pdf
}

\section{Библиография:}

1. Gutierrez L. Still dreaming, New York: W.W. Norton\&Company, 2013, 413 pages.

2. Nichols W. The DREAMers. How the Undocumented youth movement transformed the Immigrant rights debate, Stanford: Stanford University Press, 2013, 226 pages.

3. Bloomberg business week http://www.businessweek.com/

4. Congress U.S. Federal legislative information http://beta.congress.gov/

5. First Focus, bipartisan advocacy organization http://www.firstfocus.net/

6. Latino politics blog http://latinopoliticsblog.com/

7. Library of Congress http://thomas.loc.gov/home/ thomas.php

8. Migration news, scientific journal http://migration. ucdavis.edu/mn/

9. Pew Research Hispanic trends project http://www. pewhispanic.org/

10. The Center for Immigration studies, research center http://cis.org/

11. The New York Times http://www.nytimes.com/

12. The White House http://www.whitehouse.gov/

13. Truthout, nonprofit organization http://www.truthout.org/

14. United We Dream http://unitedwedream.org/

15. U.S. Citizenship and Immigration Services http:// www.uscis.gov/

16. U.S. Department of Justice http://www.justice.gov/

17. U.S. Department of Homeland security http:// www.dhs.gov/

\section{References (transliteration):}

1. Gutierrez L. Still dreaming, New York: W.W. Norton\&Company, 2013, 413 pages.

2. Nichols W. The DREAMers. How the Undocumented youth movement transformed the Immigrant rights debate, Stanford: Stanford University Press, 2013, 226 pages. 